\title{
WARNA SEBAGAI IDENTITAS MEREK PADA KEMASAN MAKANAN TRADISIONAL KEMBANG GOYANG KHAS BETAWI
}

\author{
Chyndi Mustika Dewi ${ }^{1)}$, Alviah Hairiza ${ }^{2)}$, Edo Galasro Limbong ${ }^{3)}$
}

Program Studi Desain Komunikasi Visual, Fakultas Bahasa dan Seni, Universitas Indraprasta PGRI

Jl. Nangka No. 58 C, Tanjung Barat, Jakarta 12530, Indonesia

cindymustika.d@gmail.com

\begin{abstract}
Abstrak
Warna merupakan salah satu elemen desain yang penting dalam pembuatan kemasan karena dapat menyampaikan pesan yang diinginkan oleh merek suatu produk. Memiliki kesan tertentu yang berbeda pada setiap warna dapat menjadikan warna sebagai identitas pembeda suatu merek. Perancangan ini bertujuan untuk menentukan warna yang dapat menjadi identitas dari suatu merek kembang goyang. Pemilihan oranye dan kuning sebagai warna yang digunakan dalam perancangan kemasan kembang goyang karena warna tersebut memiliki kesan yang sesuai dengan citra yang ingin ditampilkan pada produk dan juga merupakan warna yang mencolok sehingga mampu dengan mudah dilihat oleh konsumen.
\end{abstract}

Kata Kunci: warna, kemasan, tradisional, kembang goyang

\begin{abstract}
Color is one of the design elements that are important in packaging making because it can convey the message desired by the brand of a product. Having a certain different impression on each color can make the color as a distinguishing identity of a brand. The design aims to determine the color that can be the identity of a rocking brand. The selection of orange and yellow as the color used in the design of the shake packaging because the color has an impression that corresponds to the image that wants to be displayed on the product and is also a striking color so that it can easily be seen by consumers.
\end{abstract}

Keywords: color, packaging, traditional, kembang goyang

Correspondence author: Chyndi Mustika Dewi, cindymustika.d@gmail.com, Jakarta, and Indonesia

This work is licensed under a CC-BY-NC

\section{PENDAHULUAN}

Kembang goyang khas Betawi menjadi salah satu produk unggulan Provinsi DKI Jakarta yang cukup digemari oleh masyarakat. Dinamakan kembang goyang karena bentuknya yang unik seperti kelopak bunga atau kembang yang mekar. Kembang goyang khas Betawi memiliki perpaduan rasa manis dan gurih yang enak dan renyah untuk dinikmati. Terbuat dari bahan 
berkualitas, yaitu tepung beras, tepung kanji, santan, garam, kuning telur, putih telur, gula pasir yang dicampurkan, dicetak, dan digoreng dengan cara digoyang-goyang hingga adonan terlepas dari cetakan dan berwarna kuning keemasan. Menjadikan kembang goyang sebagai camilan yang sehat karena dibuat tanpa bahan pengawet.

Kembang goyang khas Betawi dapat dinikmati sebagai camilan saat bersantai bersama dengan teman ataupun keluarga yang cocok dijadikan sebagai oleh-oleh ketika berpergian. Banyak dijumpai usaha olahan camilan kembang goyang khas Betawi, tetapi masih banyak produk kembang goyang yang dikemas secara sederhana menggunakan bahan plastik, sehingga kembang goyang yang memiliki tekstur renyah mudah hancur ketika dibawa berpergian karena kemasan yang digunakan kurang bisa untuk melindungi kembang goyang. Selain itu, desain kemasan kembang goyang yang kurang menarik membuat konsumen kurang memperhatikan produk kembang goyang apabila berdampingan dengan produk kembang goyang ataupun produk camilan lainnya. Sebagai salah satu produk yang diunggulkan oleh Jakarta kembang goyang khas Betawi masih lebih diketahui oleh kalangan orang tua daripada remaja. Kembang goyang dapat menjadi camilan sehat untuk remaja menggantikan camilan lain yang pada umumnya mengandung $M S G$.

Permasalahan yang muncul dari kemasan produk kembang goyang khas Betawi dapat memengaruhi tingkat penjualan produk. Produk pesaing kembang goyang yang didesain lebih menarik dan terkesan kekinian bisa membuat produk lainnya terlihat lebih kuno. Diperlukan perancangan desain kemasan yang inovatif terhadap produk kembang goyang khas Betawi. Nantinya produk tidak hanya dipasarkan pada pasar tradisional, tetapi juga pada toko oleh-oleh, swalayan, dan toko online. Maka dari itu, desain kemasan produk harus dibuat semenarik mungkin agar bisa menarik perhatian konsumen lewat bentuk dan dekorasi kemasan. Menurut (Wahyudi \& Satriyono, 2017: 30) “... kemasan yang unik dan berbeda merupakan salah satu daya tarik visual yang cepat menyapa mata konsumen".

Salah satu yang dapat menjadi daya tarik kemasan adalah warna. Warna memiliki pengaruh yang besar dalam kehidupan manusia. Indera penglihatan manusia paling mudah menangkap warna sebelum tertarik dengan elemen visual yang lainnya. Warna dapat memengaruhi psikologi manusia ketika melihatnya karena warna memiliki makna khusus. Menurut (Nugroho, 2008) "setiap warna memberikan kesan dan identitas tertentu, walaupun hal ini bergantung pada latar belakang pengamatnya juga" sehingga warna dapat dijadikan sebagai identitas suatu produk. Warna dalam desain kemasan dapat menjadi pembeda baik itu pada kemasan produk pesaing ataupun menjadi pembeda untuk varian yang ada.

Desain kemasan kembang goyang khas Betawi harus bisa menjadi pembeda dengan produk pesaingnya dan memuat informasi yang diperlukan konsumen. Dengan warna suatu karya dapat menampilkan identitas atau citra yang ingin disampaikan yang membedakan sifat secara jelas (Anggraini \& Nathalia, 2016: 37). Dengan perbedaan kesan yang ditimbulkan oleh warna maka yang akan dipilih harus disesuaikan dengan identitas atau citraan yang ingin ditampilkan pada produk kembang goyang tersebut. Pemilihan warna yang sesuai dapat menarik perhatian dari konsumen dan membantu konsumen mengenali produk melalui warna dari kemasan sehingga dari rasa ketertarikan tersebut dapat memengaruhi konsumen untuk mencoba produk dengan membelinya.

\section{METODE PENELITIAN}

Metode penelitian ini dilakukan dengan metode penelitian kualitatif yang digunakan untuk mengolah dan menganalisis data-data yang terkumpul menjadi data yang sistematis, teratur, terstruktur dan mempunyai makna. Proses pengumpulan dalam perancangan ini adalah studi pustaka yaitu dengan mencari referensi dari buku-buku, melihat desain kemasan produk kembang goyang lainnya. Pengumpulan data juga dilakukan dengan wawancara yaitu dengan menanyakan kepada konsumen yang sudah mencoba kembang goyang khas Betawi, serta observasi langsung ke tempat penjualan kembang goyang khas Betawi, menganalisis kemasan kembang goyang khas Betawi yang ada dipasaran. 


\section{HASIL DAN PEMBAHASAN}

Tujuan pengaplikasian warna pada kemasan kembang goyang khas Betawi yaitu untuk membangun identitas merek dari produk. Maka dari itu, dalam perancangan ini akan dihasilkan kemasan yang mampu menanamkan citra merek dalam benak konsumen dan menarik perhatian target khalayak serta mempengaruhi untuk membeli produk kembang goyang khas Betawi.

Salah satu unsur penguat dari identitas produk yang ingin ditunjukan yaitu warna. Menurut (Zaichkowsky, tanpa tahun) warna sebagai unsur identitas di samping nama merek, logo, jenis font, simbol dan bentuk. Unsur-unsur yang berbeda dapat memberikan berbagai persepsi bagi konsumen dari merek-merek di pasar dan membantu untuk membedakan merek pesaing. Warna jauh lebih diingat daripada bentuk dan warna adalah titik pertama dalam mengidentifikasi suatu merek.

"Combinations of colours are superior to a single color for identification, because linking a single colour to a single manufacturer"s brand may not imply an unique origin." (Zaichkowsky, tanpa tahun). Menggunakan kombinasi warna lebih baik daripada hanya mengunakan satu warna untuk identifikasi merek. Oleh sebab itu, dalam perancangan ini akan menggunakan tiga warna sebagai identitas merek dan untuk membangun citra merek melalui psikologi warna.

Menurut (Nugroho, 2008: 35), Warna diyakini mempunyai dampak psikologis terhadap manusia. Dampak tersebut dapat dipandang dari berbagai aspek, baik dari aspek panca indra, budaya dan lain-lain. dalam perancangan warna pada kemasan ini akan menggunakan warna panas. Warna panas menurut (Nugroho, 2008) yaitu sekelompok warna dalam rentang setengah lingkaran didalam lingkaran warna mulai dari merah hingga kuning. Warna ini menjadi simbol, riang, semangat, amarah, dan sebagainya.

Warna pada desain kemasan yang dibuat akan menampilkan citra tradisional, kebersamaan, kehangatan, dan keceriaan dari produk kembang goyang. Tradisional yang dimaksud adalah menampilkan elemen estetis seperti gigi balang sebagai elemen perwakilan dari Betawi. Kebersamaan ditimbulkan dari kegiatan berkumpul bersama kerabat untuk memakan camilan kembang goyang khas Betawi bersama sehingga menimbulkan rasa kehangatan dan keceriaan saat bersama-sama.

Untuk membangun citra kehangatan digunakan warna oranye dan kuning. Kuning adalah wana emosional yang menciptakan keceriaan, persahabatan dan harapan. Oranye akan menciptakan rasa kehangatan dan ceria. Oranye dan kuning adalah warna yang cocok dengan tujuan dari produk ini karena dari penggunaan kedua warna tersebut akan memberikan kesan kegembiraan dan persahabatan. Produk ini juga memiliki target khalayak remaja dengan psikografis yang menyukai nyemil dan berkumpul bersama-sama, dengan menggunakan warna ini pada kemasan akan memberikan suasana keceriaan dan persahabatan.

Selain kedua warna tersebut, pada unsur lain yaitu ilustrasi dan tipografi pada perancangan kemasan ini, warna yang digunakan adalah putih. Sebagai warna netral dari kemasan ini, putih juga melambangkan kemurnian, tegas dan simpel. Selain itu, penggunaan warna putih karena kembang goyang khas Betawi dibuat dengan memperhatikan kebersihan dan menggunakan bahan berkualitas sehingga menjadikannya sebagai camilan yang sehat dan sangat cocok dengan citra yang diingin dibangun oleh produk dalam benak konsumen.

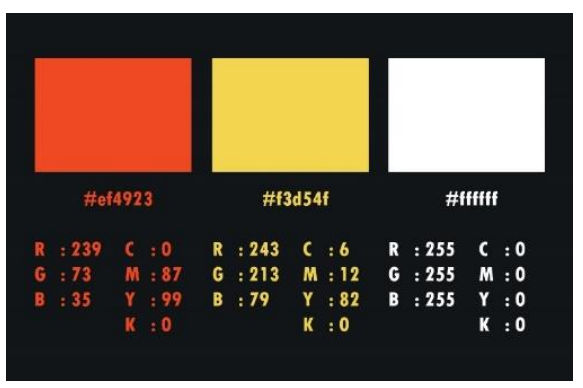

Gambar 1 Skema Warna 


\section{Hasil akhir perancangan}

Ditinjau berdasarkan konsep perancangan terkait dengan warna pada kemasan, maka dapat dilihat hasil akhir dari perancangan sebagai berikut:

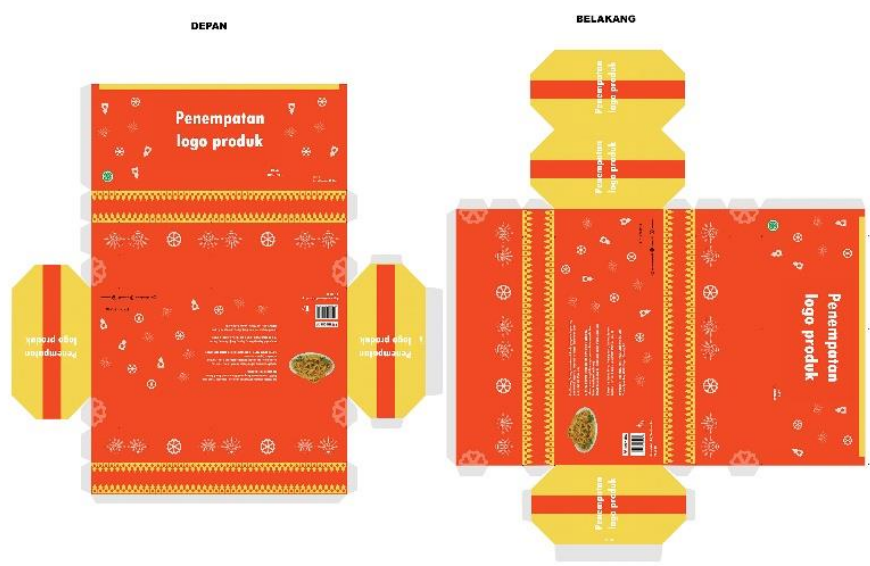

Gambar 2 Surface Kemasan Variasi 1

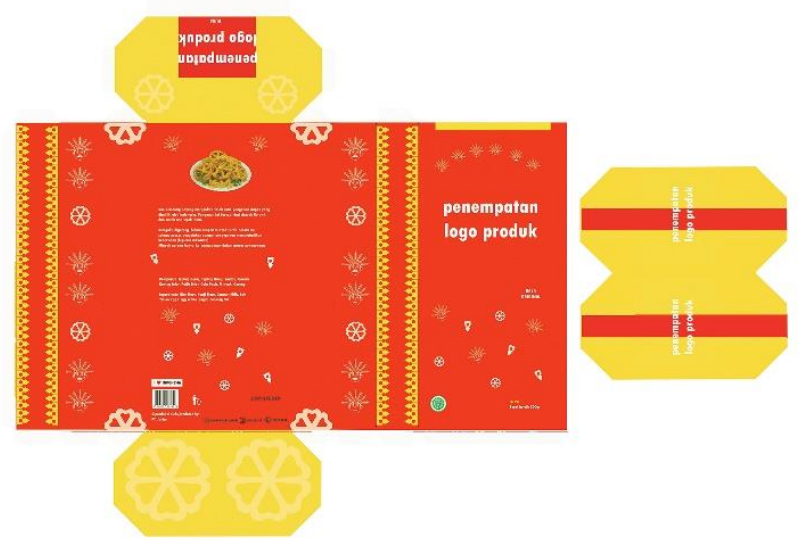

Gambar 3 Surface Kemasan Variasi 2

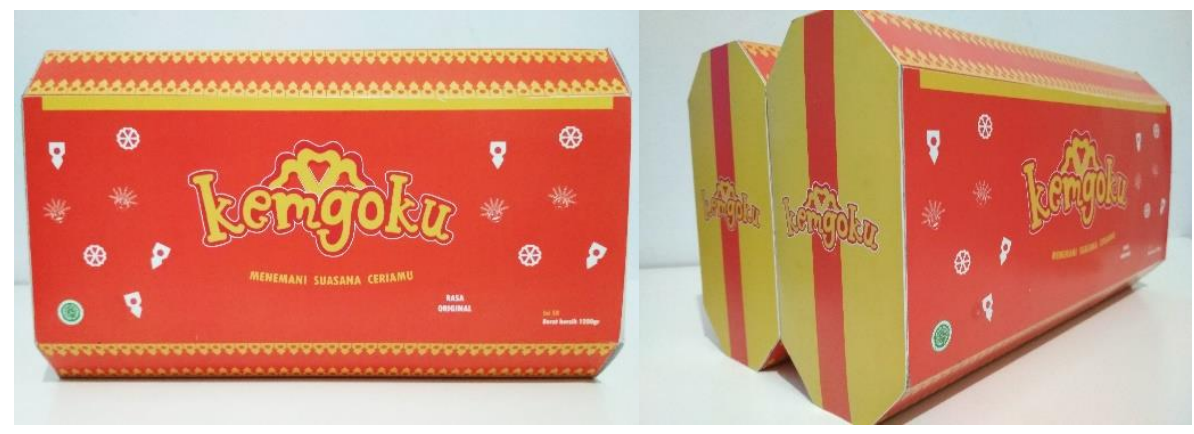

Gambar 4 Kemasan Variasi 1 Tampak Depan dan Serong 


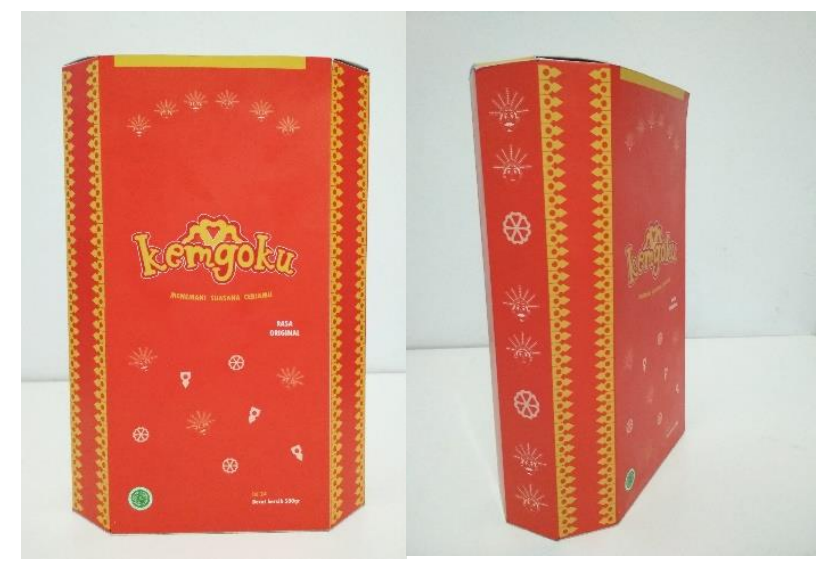

Gambar 6 Kemasan Variasi 2 Tampak Depan dan Serong

\section{SIMPULAN}

Semakin ketatnya persaingan dalam dunia kuliner di Jakarta membuat makanan tradisional harus dapat lebih mampu bersaing dengan makanan yang baru. Maka dari itu, dibutuhkan suatu daya tarik yang dapat menarik perhatian dari konsumen. Warna merupakan unsur penting dalam objek desain. Warna menjadi salah satu elemen desain yang mampu menarik perhatian karena memiliki efek psikologis ketika melihatnya. Melalui warna, identitas atau citra yang ingin disampaikan dapat ditampilkan sebagai karakter pembeda yang kuat dengan merek lainnya.

Pemilihan oranye dan kuning sebagai warna yang digunakan dalam perancangan kemasan kembang goyang karena warna tersebut memiliki kesan yang sesuai dengan citra yang ingin ditampilkan pada produk dan juga merupakan warna yang mencolok sehingga mampu dengan mudah dilihat oleh konsumen.

\section{DAFTAR PUSTAKA}

Anggraini, L., \& Nathalia, K. (2016). Desain komunikasi visual: Dasar panduan untuk pemula. Bandung: Nuansa Cedikia.

Nugroho, E. (2008). Teori warna. Jakarta: Gramedia.

Wahyudi, N., \& Satriyono, S. (2017). Mantra kemasan juara. Jakarta: Elex Media Komputindo.

Zaichkowsky, J. L. (tanpa tahun). Strategies for distinctive brands. Brand Management, Special Is. Diakses dari http://www.sfu.ca/ zaichkow/strategiesforbrands.pdf 